\section{Research Square}

Preprints are preliminary reports that have not undergone peer review.

They should not be considered conclusive, used to inform clinical practice, or referenced by the media as validated information.

\title{
Simultaneous Experimental Analysis of Oil Content and Molecular Composition of Shale Fractions
}

\author{
Bowei Zhang ( $2857602305 @ q q . c o m)$ \\ Northeast Petroleum University \\ Juhe Zhang \\ Exploration and Development Research Institute囚Daqing
}

\author{
Research Article \\ Keywords: Songliao Basin, shale oil, fraction, molecular composition, simultaneous analysis, oiliness, mobility \\ Posted Date: January 31st, 2022 \\ DOI: https://doi.org/10.21203/rs.3.rs-1218547/v2 \\ License: @ (i) This work is licensed under a Creative Commons Attribution 4.0 International License. Read Full License
}




\section{Abstract}

The important research content and basis of exploration and development is to evaluate the reservoir property, oil bearing property, fluidity and compressibility of shale reservoir.The key of exploration and development is to evaluate the oil-bearing and fluidity of shale reservoir.In this paper, the "shale oil content and fine components synchronous experimental analysis device" is used. Five temperature ranges of $30{ }^{\circ} \mathrm{C}-90^{\circ} \mathrm{C}, 90^{\circ} \mathrm{C}-150{ }^{\circ} \mathrm{C}, 100{ }^{\circ} \mathrm{C}-200{ }^{\circ} \mathrm{C}, 150{ }^{\circ} \mathrm{C}-250{ }^{\circ} \mathrm{C}$ and $250^{\circ} \mathrm{C}-300{ }^{\circ} \mathrm{C}$ were adopted. The heating rate of each temperature segment was $25^{\circ} \mathrm{C} / \mathrm{min}$, and the final temperature was kept constant for 5 min. The oil content of shale (pyrolysis S1) was cut into five fractions.Simultaneous determination of oil content and molecular composition of shale fractions,and the external standard method was used to evaluate the oil content and fluidity.The results show that the five fractions of shale are mainly composed of nC1nC9 gas, nC10-nC15 gasoline, nC12-nC20 kerosene, nC15-nC22 diesel oil and nC18-nC26 heavy oil of the first member of Qingshangkou formation in Songliao basin. There are differences in the fractionation and oil content characteristics of samples with different maturity in different wells. The parent material, properties and quality of crude oil are reflected in shale. The higher the maturity of shale oil is, the more light components are, the larger the light / heavy ratio parameter value of (gasoline + kerosene + diesel) and heavy oil is, the better the fluidity is, and the easier to exploit effectively.

\section{Introduction}

A new round of technological revolution in the global oil and gas industry has been brought about by the breakthrough of shale oil in North America, and a worldwide upsurge of shale oil exploration has been set off ${ }^{[4-6,8,14-15]}$ (Sonnenberg S A and Pramudito A,2009;ZOU Caineng et al,2013;NIE Haikuan et al,2016;NING Fangxing, 2015;ZHU Deshun,2016;LIU Bo et al,2012). The recoverable reserves of shale oil in the world can reach 4.86×10 ${ }^{10} \mathrm{t}$. Exploration and practice of shale oil exploration has been carried out in several basins in China ${ }^{[14]}$ (ZOU Caineng et al,2014). Industrial oil flow was obtained in Songliao Basin, Ordos Basin [2-3,13] (YANG Hua et al,2013,2016;GAO Gang et al,2013;CUI Jingwei et al,2015), Bohai Bay Basin [1,9-11] (BAO Youshu et al,2016;WANG Yong et al,2016;WANG Xuefei et al,2013;SHAN Yansheng et al,2016), Nanxiang basin ${ }^{[16-17]}$ (ZHU Jingxiu et al,2015;ZHANG Xinwen et al,2014) and Junggar basin ${ }^{[7,18]}$ (QIU Zhen et al,2016;ZHI Dongming et al,2019), these positive developments show good prospects in shale oil exploration and development in China ${ }^{[14]}$ (ZOU Caineng et al,2014).

The important research content and basis of exploration and development is to evaluate the reservoir properties, oil bearing properties, fluidity and compressibility of shale reservoirs. The key in exploration and development is to evaluate oil bearing properties and fluidity. It is of great significance to select "desserts" in shale oil and evaluate reserves and resources. The oil content (pyrolysis S1)of shale is mainly detected by a Rock-Eval 6 instrument, or fine hydrocarbon componentsare detected by gas chromatography in mudstone, which is the main experimental method in China and abroad. However, it is difficult to realize the oil content and hydrocarbon molecular composition of the shale fraction by synchronous experimental analysis. Fine evaluation is restricted in oil bearing and fluidity in shale reservoirs.

The simultaneous analysis method for shale fraction oil content and its molecular composition was kicked out in this paper. A synchronous experimental analysis device was developed and used to determine the shale oil content and fine components. Five temperature ranges of $30{ }^{\circ} \mathrm{C}-90{ }^{\circ} \mathrm{C}, 90{ }^{\circ} \mathrm{C}-150{ }^{\circ} \mathrm{C}, 100$ ${ }^{\circ} \mathrm{C}-200{ }^{\circ} \mathrm{C}, 150{ }^{\circ} \mathrm{C}-250{ }^{\circ} \mathrm{C}$ and $250{ }^{\circ} \mathrm{C}-300{ }^{\circ} \mathrm{C}$ were adopted. The heating rate of each temperature segment was $25^{\circ} \mathrm{C} / \mathrm{min}$, and the final temperature was kept constant for $5 \mathrm{~min}$. The oil content of shale (pyrolysis S1) was cut into five fractions. Simultaneous determination of the oil content and molecular composition of shale fractions and the external standard method were used to evaluate the oil content and fluidity. To meet the needs of geological experiment technology for shale oil exploration and to evaluate the oil content and fluidity in shale, we use the oil content, molecular composition and light weight ratio of fractions to analyze the parameter indexes.

\section{Experimental Methods}

\subsection{Experimental instruments and samples}

Testing instrument: Simultaneous experimental analysis device for oil content and fine components in shale. It consists of an oil content detection unit, capture and thermal release unit, fine component detection unit and synchronous analysis control unit.

Test sample: The particle size of shale is $1-3 \mathrm{~mm}$, and the sample weight is $50 \mathrm{mg}$.

\subsection{Oil content analysis conditions of shale fraction}

Main analysis conditions of shale oil content: The pyrolysis furnace is set with five temperature ranges of $30^{\circ} \mathrm{C}-90^{\circ} \mathrm{C}\left(\mathrm{S}_{1-0}\right), 90^{\circ} \mathrm{C}-150^{\circ} \mathrm{C}\left(\mathrm{S}_{1-1}\right), 150^{\circ} \mathrm{C}-200^{\circ} \mathrm{C}$ $\left(\mathrm{S}_{1-2}\right), 200^{\circ} \mathrm{C}-250^{\circ} \mathrm{C}\left(\mathrm{S}_{1-3}\right), 250^{\circ} \mathrm{C}-300^{\circ} \mathrm{C}\left(\mathrm{S}_{1-4}\right)$, The temperature programmed rate of each temperature segment was $25^{\circ} \mathrm{C} / \mathrm{min}$, and the final temperature was kept constant for $5 \mathrm{~min}$. The purity of carrier gas helium is $99.999 \%$, and the working pressure is $0.90 \sim 1.00 \mathrm{MPa}$. The purity of hydrogen gas is $99.999 \%$, and the working pressure is $0.20 \sim 0.30$ The working pressure of auxiliary gas air is $0.50 \sim 0.60 \mathrm{MPa}$.

\subsection{Hydrocarbon enrichment and thermal release conditions of shale oil fractions}

Main enrichment conditions: Liquid nitrogen was used for freezing enrichment. Liquid nitrogen completely submerged the trap. The freeze concentration time was 7.4 min for $S_{1-0}, 7.4$ min for $\mathrm{s}_{1-1}, 7$ min for $S_{1-2}, 7$ min for $S_{1-3}$ and 7 min for $\mathrm{s}_{1-4}$.

Main conditions of heat release: The pyrolytic temperature was $300^{\circ} \mathrm{C}$, the temperature control accuracy was $0.1^{\circ} \mathrm{C}$, and the thermal release time was 10 min. The temperature of the pipelines and valves of the capture and heat release unit is $300{ }^{\circ} \mathrm{C}$. 
Main analytical conditions for molecular components of fractions: Analysis column $50 \mathrm{~m} \times 0.20 \mathrm{~mm} \times 0.5 \mu \mathrm{M}$. The temperature of FID detector is $320{ }^{\circ} \mathrm{C}$.

Gas: Hydrogen, the flow rate was $45 \mathrm{ml} / \mathrm{min}$.

Oxidant gas: Atmosphere, the flow rate was $450 \mathrm{ml} / \mathrm{min}$.

$\mathbf{S}_{1-0}$ : The column temperature was $35^{\circ} \mathrm{C}$ and kept constant for $5 \mathrm{~min}$. The temperature was raised to $90^{\circ} \mathrm{C}$ at $5{ }^{\circ} \mathrm{C} / \mathrm{min}$ until the components were discharged.

$\mathrm{S}_{1-1}$ : The column temperature was $35^{\circ} \mathrm{C}$ and kept constant for $5 \mathrm{~min}$. The temperature was raised to $150{ }^{\circ} \mathrm{C}$ at $5{ }^{\circ} \mathrm{C} / \mathrm{min}$ until the components were discharged.

$\mathrm{S}_{1-2}$ : The column temperature was $35^{\circ} \mathrm{C}$ and kept constant for $5 \mathrm{~min}$. The temperature was raised to $200{ }^{\circ} \mathrm{C}$ at $5^{\circ} \mathrm{C} / \mathrm{min}$ until the components were discharged.

$\mathrm{S}_{1-3}$ : The column temperature was $35^{\circ} \mathrm{C}$ and kept constant for $5 \mathrm{~min}$. The temperature was raised to $250^{\circ} \mathrm{C}$ at $5{ }^{\circ} \mathrm{C} / \mathrm{min}$ until the components were discharged.

$\mathrm{S}_{1-4}$ : The column temperature was $35^{\circ} \mathrm{C}$ and kept constant for $5 \mathrm{~min}$. The temperature was raised to $300{ }^{\circ} \mathrm{C}$ at $5{ }^{\circ} \mathrm{C} / \mathrm{min}$ until the components were discharged.

\subsection{Qualitative and quantitative analysis of the oil fraction and hydrocarbon molecular composition in shale}

Qualitative analysis was carried out by standard sample, retention time and literature. The standard sample appearance method was used for quantitative analysis. The data parameters of oil content $(\mathrm{mg} / \mathrm{g})$ and hydrocarbon molecular composition of five fractions in shale can be obtained.

\section{Experimental Process And Steps}

The oil content and molecular composition of fractions in shale were analyzed according to the following process and steps:

1. Fresh core samples were collected at the shale oil drilling site and cryopreserved in liquid nitrogen. Alternatively, conventional shale samples were collected on site.

2. Turn on the carrier gas of "Synchronous experimental analysis device in oil content and fine components in shale", turn on the power switch of chemical workstation, connect air and hydrogen, setting the condition parameters of synchronous analysis.

3. When the experimental device reaches the set value of the analysis condition parameters, the reference material of mudstone is weighed for experimental analysis. Get the synchronous analysis data.

4. The samples weighed in step 1 were analyzed with the same experimental parameters in step 2 . Get the synchronous analysis data.

5. Using the analysis data of step 3 , the analysis data of step 4 were quantified by an external method, and the oil content and molecular composition analysis parameters of the shale fraction were obtained.

6. The analysis parameters obtained in step 5 are used to evaluate the oil-bearing properties and fluidity in shale.

\section{Experimental Results And Discussion}

\subsection{Oil content and molecular composition of shale fractions}

\subsubsection{Characteristics of oil content and molecular composition of fractions from frozen shale samples in situ}

Characteristics of the oil content and molecular composition of frozen (liquid nitrogen) shale samples collected by coring at the drilling site (Fig. 1). The oil contents of the $S_{1-0}, S_{1-1}, S_{1-2}, S_{1-3}$ and $S_{1-4}$ fractions of $1620.43 \mathrm{~m}$ deep shale samples from well cha21 are $1.25 \mathrm{mg} / \mathrm{g}, 0.44 \mathrm{mg} / \mathrm{g}, 0.33 \mathrm{mg} / \mathrm{g}, 0.31 \mathrm{mg} / \mathrm{g}$ and $0.38 \mathrm{mg} / \mathrm{g}$, respectively. The main molecular compositions of the samples are $\mathrm{nC}_{1}-\mathrm{nC}_{9}, \mathrm{nC}_{1}-\mathrm{nC}_{15}, \mathrm{nC}_{12}-\mathrm{nC}_{20}, \mathrm{nC}_{15}-\mathrm{nC}_{22}$, and $\mathrm{nC}_{18}-\mathrm{nC}_{26}$. The five temperature fractions were mainly gas, gasoline, kerosene, diesel oil and heavy oil (Department of Organic Chemistry, 1984). The contents of the samples were 46\%, 16\%, $12 \%, 11 \%$, and $15 \%$, and the main components were gas and gasoline. The parent material type is $\|_{1}$, and the maturity Ro is $0.80 \%$, which is in the early stage of maturity. This kind of sample has the highest gas fraction.

\subsubsection{Characteristics of oil content and molecular composition of fractions from conventional shale samples}

Simultaneous analysis of oil content and molecular composition of shale fractions collected by core library show that(Fig. 2),the oil contents of $\mathrm{S}_{1-0}, \mathrm{~S}_{1-1}, \mathrm{~S}_{1-2}$ $\mathrm{S}_{1-3}$ and $\mathrm{S}_{1-4}$ fractions of $1625.3 \mathrm{~m}$ shale samples from well Pu53 are $0 \mathrm{mg} / \mathrm{g}, 0.04 \mathrm{mg} / \mathrm{g}, 0.17 \mathrm{mg} / \mathrm{g}, 0.44 \mathrm{mg} / \mathrm{g}$ and $1.42 \mathrm{mg} / \mathrm{g}$. The main distribution of its molecular composition was not detected; $\mathrm{nC}_{11}-\mathrm{nC}_{15}$ ( $\mathrm{n}$-alkane degradation), $\mathrm{nC}_{13}-\mathrm{nC}_{17}$ (n-alkane degradation), $\mathrm{nC}_{15}-\mathrm{nC}_{20}\left(\mathrm{n}\right.$-alkane degradation) and $\mathrm{nC}_{18}$ $\mathrm{nC}_{25}$ (n-alkane degradation) accounted for $0 \%, 2 \%, 8 \%, 21 \%$ and $69 \%$, respectively. The $n$-alkanes of gasoline, kerosene and diesel oil were biodegraded; they were mainly composed of heavy oil, and no biodegradation occurred. The type of hydrocarbon parent material is II1, and the maturity Ro is $0.83 \%$, which is in the early mature stage of hydrocarbon expulsion. The oil contents of the $\mathrm{S}_{1-0}, \mathrm{~S}_{1-1}, \mathrm{~S}_{1-2}, \mathrm{~S}_{1-3}$ and $\mathrm{S}_{1-4}$ fractions of the $2135.78 \mathrm{~m}$ shale sample in well syy2 are $0 \mathrm{mg} / \mathrm{g}, 0.83 \mathrm{mg} / \mathrm{g}, 1.19 \mathrm{mg} / \mathrm{g}, 0.93 \mathrm{mg} / \mathrm{g}$ and $0.66 \mathrm{mg} / \mathrm{g}$, respectively. The main distribution of its molecular composition was not detected. The contents of 
$\mathrm{nC}_{13}-\mathrm{nC}_{20}, \mathrm{nC}_{17}-\mathrm{nC}_{23}, \mathrm{nC}_{20}-\mathrm{nC}_{26}$ and $\mathrm{nC}_{23}-\mathrm{nC}_{29}$ accounted for $0 \%, 23 \%, 33 \%, 26 \%$ and $18 \%$, respectively. It is mainly composed of kerosene, diesel oil and gasoline. The type of hydrocarbon parent material is $I 11$, and the maturity Ro is $1.19 \%$ in the mature stage. The oil contents of the $S_{1-0}, S_{1-1}, S_{1-2}, S_{1-3}$ and $S_{1-4}$ fractions of $2557.36 \mathrm{~m}$ shale samples from well Gy 1 are $0.06 \mathrm{mg} / \mathrm{g}, 0.63 \mathrm{mg} / \mathrm{g}, 1.17 \mathrm{mg} / \mathrm{g}, 1.27 \mathrm{mg} / \mathrm{g}$ and $0.16 \mathrm{mg} / \mathrm{g}$, respectively. Its molecular composition is mainly distributed in $\mathrm{nC}_{10}-\mathrm{nC}_{13}, \mathrm{nC}_{11}-\mathrm{nC}_{16}, \mathrm{nC}_{12}-\mathrm{nC}_{18}, \mathrm{nC}_{13}-\mathrm{nC}_{21}, \mathrm{nC}_{15}-\mathrm{nC}_{20}$, and the contents were $2 \%, 19 \%, 35 \%, 39 \%$ and $5 \%$, respectively. It is mainly composed of diesel oil, the type of hydrocarbon parent material is type $\mathrm{I}$, and the maturity Ro is $1.67 \%$, which is in the high maturity stage. The oil content and molecular composition of the fractions are different in different well shale samples of the first member of the Qingshankou Formation. This reflects the differences in shale with different parent material types and maturities.

\subsection{Evaluation of oil bearing and fluidity of shale reservoir}

\subsubsection{Evaluation of oil bearing property of shale reservoir}

The larger the oil content of the shale fraction and its value, the better the oil-bearing property of the reservoir under the same analytical conditions. The oil contents of shale in wells cha21, Pu53, Gy 1 and syy 2 are $1.33 \mathrm{mg} / \mathrm{g}, 2.09 \mathrm{mg} / \mathrm{g}, 3.29 \mathrm{mg} / \mathrm{g}$ and $3.61 \mathrm{mg} / \mathrm{g}$, respectively. In terms of oil content, syy2 and Gy 1 are the best, Pu53 is the second, and cha21 is the last (Table 1). However, it should be noted that although the oil content of well Pu53 is higher than that of well cha21, the components of gasoline, kerosene and diesel oil in the first member of the Qingshankou Formation in well Pu53 are biodegraded, the degradation of $n$-alkanes is serious, the crude oil becomes thicker and the oil quality is obviously worse.

Table 1 Characteristics of fraction content and molecular composition of shale with different maturity

\begin{tabular}{|c|c|c|c|c|c|c|c|c|c|}
\hline $\begin{array}{l}\text { Well } \\
\text { name }\end{array}$ & $\begin{array}{l}\text { Deep } \\
(\mathrm{m})\end{array}$ & $\begin{array}{l}\text { TOC } \\
(\%)\end{array}$ & $\begin{array}{l}\text { Ro } \\
\text { (\%) }\end{array}$ & $\begin{array}{l}\mathrm{S}_{1-} \\
0(\%, \mathrm{mg} / \mathrm{g}, \text { Carbon } \\
\text { number range })\end{array}$ & $\begin{array}{l}\mathrm{S}_{1-} \\
{ }_{1}(\%, \mathrm{mg} / \mathrm{g}, \text { Carbon } \\
\text { number range })\end{array}$ & $\begin{array}{l}\mathrm{S}_{1-} \\
{ }_{2}(\%, \mathrm{mg} / \mathrm{g}, \text { Carbon } \\
\text { number range ) }\end{array}$ & $\begin{array}{l}\mathrm{S}_{1-} \\
{ }_{3}(\%, \mathrm{mg} / \mathrm{g}, \text { Carbon } \\
\text { number range })\end{array}$ & $\begin{array}{l}\mathrm{S}_{1-} \\
{ }_{4}(\%, \mathrm{mg} / \mathrm{g}, \text { Carbon } \\
\text { number range })\end{array}$ & $\begin{array}{l}\text { Oil } \\
\text { content(\% } \\
\text { number rá }\end{array}$ \\
\hline $\begin{array}{l}\text { Cha21 } \\
\text { (frozen) }\end{array}$ & 1620.43 & 2.62 & 0.80 & $\begin{array}{l}\text { 46,1.25, } \\
\mathrm{nC}_{1} \sim \mathrm{nC}_{11}\end{array}$ & $\begin{array}{l}\text { 16,0.44, } \\
\mathrm{nC}_{10} \sim \mathrm{nC}_{15}\end{array}$ & $\begin{array}{l}\text { 12,0.33, } \\
\mathrm{nC}_{12} \sim \mathrm{nC}_{20}\end{array}$ & $\begin{array}{l}\text { 11,0.31, } \\
\mathrm{nC}_{15} \sim \mathrm{nC}_{22}\end{array}$ & $\begin{array}{l}15,0.38 \\
\mathrm{nC}_{18} \sim \mathrm{nC}_{26}\end{array}$ & 100,2.71, \\
\hline Cha21 & 1620.43 & 2.62 & 0.80 & l & $\begin{array}{l}\text { 29,0.39, } \\
\mathrm{nC}_{10} \sim \mathrm{nC}_{15}\end{array}$ & $\begin{array}{l}\text { 26,0.34, } \\
\mathrm{nC}_{12} \sim \mathrm{nC}_{20}\end{array}$ & $\begin{array}{l}\text { 24,0.32, } \\
\mathrm{nC}_{15} \sim \mathrm{nC}_{22}\end{array}$ & $\begin{array}{l}\text { 21,0.28, } \\
\mathrm{nC}_{18} \sim \mathrm{nC}_{26}\end{array}$ & 100,1.33, \\
\hline Pu53 & 1625.30 & 2.86 & 0.83 & / & $\begin{array}{l}2,0.04 \\
\mathrm{nC}_{11} \sim \mathrm{nC}_{15}\end{array}$ & $\begin{array}{l}\text { 8,0.17, } \\
\mathrm{nC}_{13} \sim \mathrm{nC}_{17}\end{array}$ & $\begin{array}{l}21,0.44 \\
\mathrm{nC}_{15} \sim \mathrm{nC}_{20}\end{array}$ & $\begin{array}{l}69,1.42 \\
\mathrm{nC}_{18} \sim \mathrm{nC}_{25}\end{array}$ & 100,2.09, \\
\hline Syy2 & 2135.78 & 2.39 & 1.19 & / & $\begin{array}{l}\text { 23,0.83, } \\
\mathrm{nC}_{14} \sim \mathrm{nC}_{21}\end{array}$ & $\begin{array}{l}33,1.19 \\
\mathrm{nC}_{16} \sim \mathrm{nC}_{24}\end{array}$ & $\begin{array}{l}26,0.93 \\
\mathrm{nC}_{19} \sim \mathrm{nC}_{26}\end{array}$ & $\begin{array}{l}\text { 18,0.66, } \\
\mathrm{nC}_{22} \sim \mathrm{nC}_{29}\end{array}$ & 100,3.61, \\
\hline Gy1 & 2557.36 & 4.30 & 1.67 & $\begin{array}{l}2,0.06 \\
\mathrm{nC}_{10} \sim \mathrm{nC}_{13}\end{array}$ & $\begin{array}{l}\text { 19,0.63, } \\
\mathrm{nC}_{11} \sim \mathrm{nC}_{16}\end{array}$ & $\begin{array}{l}35,1.17 \\
\mathrm{nC}_{12} \sim \mathrm{nC}_{18}\end{array}$ & $\begin{array}{l}39,1.27 \\
\mathrm{nC}_{13} \sim \mathrm{nC}_{21}\end{array}$ & $\begin{array}{l}5,0.16 \\
\mathrm{nC}_{15} \sim \mathrm{nC}_{20}\end{array}$ & $100,3.29$ \\
\hline $\begin{array}{l}\text { Gy1 } \\
\text { (frozen) }\end{array}$ & 2570.65 & 2.33 & 1.67 & $\begin{array}{l}\text { 31,1.46, } \\
\mathrm{nC}_{7} \sim \mathrm{nC}_{12}\end{array}$ & $\begin{array}{l}33,1.53 \\
\mathrm{nC}_{10} \sim \mathrm{nC}_{16}\end{array}$ & $\begin{array}{l}\text { 18,0.85, } \\
\mathrm{nC}_{11} \sim \mathrm{nC}_{18}\end{array}$ & $\begin{array}{l}\text { 11,0.50, } \\
\mathrm{nC}_{14} \sim \mathrm{nC}_{20}\end{array}$ & $\begin{array}{l}\text { 7,0.31, } \\
\mathrm{nC}_{17} \sim \mathrm{nC}_{23}\end{array}$ & 100,4.65, \\
\hline
\end{tabular}

\subsubsection{Fluidity evaluation of shale reservoir}

Under the same or similar reservoir physical properties, the larger the light component proportion and the smaller the heavy component proportion of shale oil, the better the reservoir crude oil fluidity. The gas fraction in the conventional shale sample is very easy to lose; therefore, we adopt (s1-1 + S1-2 + S1-3)/s1-4, that is, (steam + coal + diesel)/heavy oil ratio (light weight ratio parameter). This parameter is relatively less affected by light hydrocarbon loss. We use this parameter to evaluate crude oil fluidity in shale reservoirs (Table 1). The light weight ratios of wells cha21, Pu53, syy2 and Gy1 were 3.76, $0.45,4.56$ and 18.6 , the order of liquidity was Gy $1>$ syy $2>$ cha21 > Pu53, and their maturity Ro values were $0.80 \%, 0.83 \%, 1.19 \%$ and $1.67 \%$, respectively. Therefore, the higher the maturity is, the better the fluidity of shale oil. However, the crude oil maturity RO of well Pu53 is slightly higher than that of well cha21; because of the degradation of crude oil in well Pu53, the fluidity of well Pu53 worsens. According to the results of exploration and testing, the fracturing of Cha21, Syy2 and Gy1 shale can obtain industrial oil flow, so (steam + coal + diesel)/heavy oil $\geq 3$ is taken as the evaluation boundary value of liquidity desserts.

\section{Conclusion}

1. The oil content $S 1$ of the first member of the Qingshankou Formation in the Songliao Basin is cut into 5 fractions at temperature. $S_{1-0}$ fraction is mainly $\mathrm{nC}_{1}-\mathrm{nC}_{9}$ gas component, $\mathrm{S}_{1-1}$ fraction is mainly $\mathrm{nC}_{10}-\mathrm{nC}_{15}$ gasoline component, $\mathrm{S}_{1-2}$ fraction is mainly $\mathrm{nC}_{12}-\mathrm{nC}_{20}$ kerosene component, $\mathrm{S}_{1-3}$ fraction is mainly $\mathrm{nC}_{15}-\mathrm{nC}_{22}$ diesel component, $\mathrm{S}_{1-4}$ fraction is mainly $\mathrm{nC}_{18}-\mathrm{nC}_{26}$ heavy oil component. The differences in fractionation and oil content characteristics of different wells and maturity samples reflect the parent material, properties and quality of shale oil. Generally, the higher the maturity of shale oil, the more light components there are, the better the fluidity, and the easier to effectively exploit, (steam + coal + diesel)/heavy oil $\geq 3$ is taken as the evaluation boundary value of shale oil liquidity desserts. 
2. There are obvious differences in oil content and molecular composition between liquid nitrogen freezing and conventional core library sampling in shale drilling of the first member of Qingshankou Formation in Songliao basin. The former has a high oil content and is mainly composed of gas and gasoline. The oil content of the latter fraction is relatively low and is mainly composed of gasoline, kerosene and diesel oil, while the biodegraded shale sample has a low oil content and is dominated by a heavy oil component. The gas components of mature and highly mature samples collected and analyzed by conventional methods were almost lost, it is more accurate to evaluate the mobility of shale oil by the parameters of diesel oil (steam + coal + diesel)/heavy oil, and the analysis and evaluation of liquid nitrogen frozen or pressure maintaining sealed coring samples in drilling site is more accurate.

\section{Declarations}

Availability of data and materials: All data generated or analysed during this study are included in this published article.

Competing interests: No competing interest.

Funding: 1. National Natural Science Foundation of China Youth Science Fund Project 42002140;

2. Youth Fund Project of Northeast Petroleum University 2018QNL-23.

Authors' contributions: Zhang Bowei and Zhang Juhe wrote the main manuscript text, and Zhang Bowei prepared Figures 1-2 and Table 1.

Acknowledgments: First, I would like to extend my sincere gratitude to my supervisor, Fu Guang, for his instructive advice and useful suggestions on my thesis. I am deeply grateful for his help in the completion of this thesis. I am also deeply indebted to all the other tutors and teachers in translation studies for their direct and indirect help to me. Special thanks should go to my friends who have put considerable time and effort into their comments on the draft. Finally, I am indebted to my parents for their continuous support and encouragement.

Authors' information (optional): Zhang Bowei, male, born in May 1989, received a bachelor's degree from Changjiang University in 2011, a master's degree from Southwest Petroleum University in 2014 and a doctor's degree from Northeast Petroleum University in 2017. He is now a teacher at the School of Earth Sciences of Northeast Petroleum University, mainly engaged in geological resource and geological engineering research. Email》857602305@qq.com

\section{References}

1. BAO Youshu, ZHANG Linye, ZHANG Jingong, et al.(2016) Factors influencing mobility of paleogene shale oil in Dongying Sag,Bohai Bay Basin. Oil and Gas Geology. 37, 408-414.

2. CUI Jingwei, ZHU Rukai, WU Songtao, et al. (2015) Optimization and distribution of shale oil sweetspots area and Chang7 Member, Ordos Basin, NW China. Journal of Jilin University (Earth Science Edition). 45 (S1), 169-170.

3. GAO Gang, LIU Xianyang, WANG Yinhui, et al. (2013) Characteristics and resource potential of the shale oil of Chang7 Layer in Longdong area, Ordos Basin. Earth Science Frontiers. 20 (2), 140-146.

4. LIU Bo, L Yanfang, ZHAO Rong, et al. (2012) Formation overpressure and shale oil enrichment in the shale system of Lucaogou Formation, Malang Sag, Santanghu Basin, NW China. Petroleum Exploration and Development. 39 (6), 699-705.

5. NIE Haikuan, ZHANG Peixian, BIAN Ruikang, et al. (2016) Oil accumulation characteristics of China continental shale. Earth Science Frontiers. 23 (2), 5562.

6. NING Fangxing. (2015) The main control factors of shale oil enrichment in Jiyang Depression. Acta Petrolei Sinica. 36 (8), $905-914$.

7. QIU Zhen, LU Bin, SHI Zhensheng, et al. (2016) Residual accumulation and resource assessment of shale oil from the Permian Lucaogou Formation in Jimusar Sag. Natural Gas Geoscience. 27 (10), 1817-1827, 1847.

8. Sonnenberg S A, Pramudito A. (2009) Petroleum geology of the giant Elm Coulee field, Williston Basin. AAPG Bulletin. 93(9), 1127-1153.

9. SHAN Yansheng, ZHANG Jinchuan, LI Xiaoguang, et al. (2016) Hydrocarbon enrichment conditions and distribution in continental shale, West Liaohe Sag,Bohai Bay Basin. Petroleum Geology and Experiment. 38 (4), 496-501.

10. WANG Yong, WANG Xuejun, SONG Guoqi, et al. (2016) Genetic connection between mud shale lithofacies and shale oil enrichment in Jiyang Depression, Bohai Bay Basin. Petroleum Exploration and Development. 43 (5), 696-704.

11. WANG Xuefei, LI Linlin, XUE Haitao, et al. (2013) Classification and evaluation of the shale oil resource potential in Lower Member of ES3 of Bonan Subsag. Petroleum Geology and Oilfield Development in Daqing. 32 (5), 159-164.

12. YANG Hua, NIU Xiaobing, XU Liming, et al. (2016) Exploration potential of shale oil and Chang7 Member, Upper Triassic Yanchang Formation, Ordos Basin, NW China. Petroleum Exploration and Development. 43 (4),511-520.

13. YANG Hua, LI Shixiang, LIU Xianyang. (2013) Characteristics and resource propects of tight oil and shale oil in Ordos Basin. ActaPetrolei Sinica. 34 (1), 110.

14. ZOU Caineng, YANG Zhi, CUI Jingwei, et al. (2013) Formation mechanism, geological characteristics and development strategy of nonmarine shale oil in China. Petroleum Exploration and Development. 40 (1),14-26.

15. ZHU Deshun. (2016) Accumulation pattern of shale oil in Dongying Sag and Zhanhua Sag, Bohai Bay Basin. Xinjiang Petroleum Geology. 37 (3), $270-274$.

16. ZHU Jingxiu, ZHANG Xinwen, LUO Xi, et al. (2015) Continental shale oil resources and favorable area evaluation of Biyang Depression. Petroleum Geology and Engineering. 29(5), 38-45. 
17. ZHANG Xinwen, LI Jijun, ZHU Jingxiu, et al. (2014) Resource evaluation and favorable area prediction on rich section of shale oil in Biyang Depression. Fault-Block Oil and Gas Field. 21(3), 301-304.

18. ZHI Dongminga, SONG Yong, HE Wenjun, JIA Xiyu, ZOU Yang, HUANG Liliang. (2019) Geological Characteristics, Resource Potential and Exploration Direction of Shale Oil in Middle-Lower Permian, Junggar Basin. XINJIANG PETROLEUM GEOLOGY. 40 (4), 389-401.

\section{Figures}
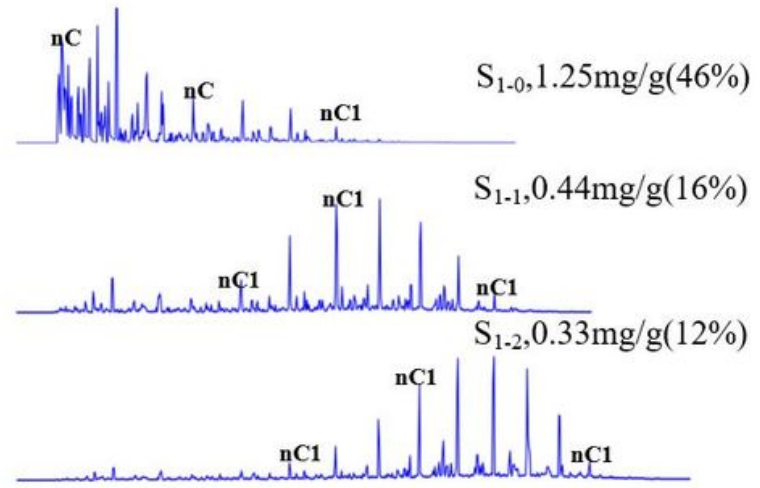

$\mathrm{S}_{1-3}, 0.31 \mathrm{mg} / \mathrm{g}(11 \%)$
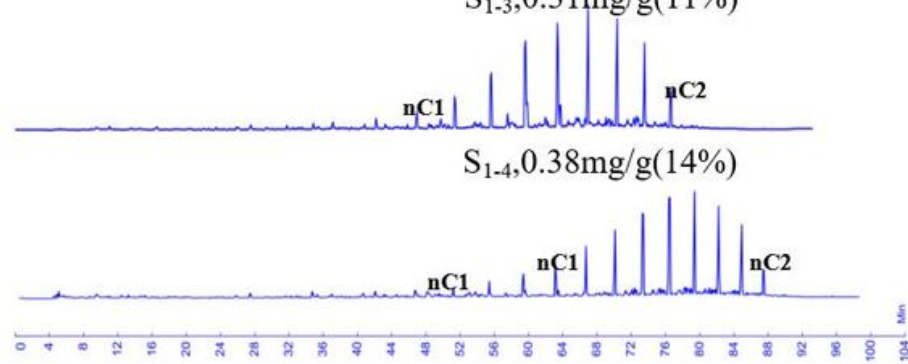

Liquid nitrogen frozen shale samples from well cha21,1620.43m

$\left(\mathrm{S}_{1}=2.71 \mathrm{mg} / \mathrm{g}, \mathrm{Ro}=0.80 \%\right)$
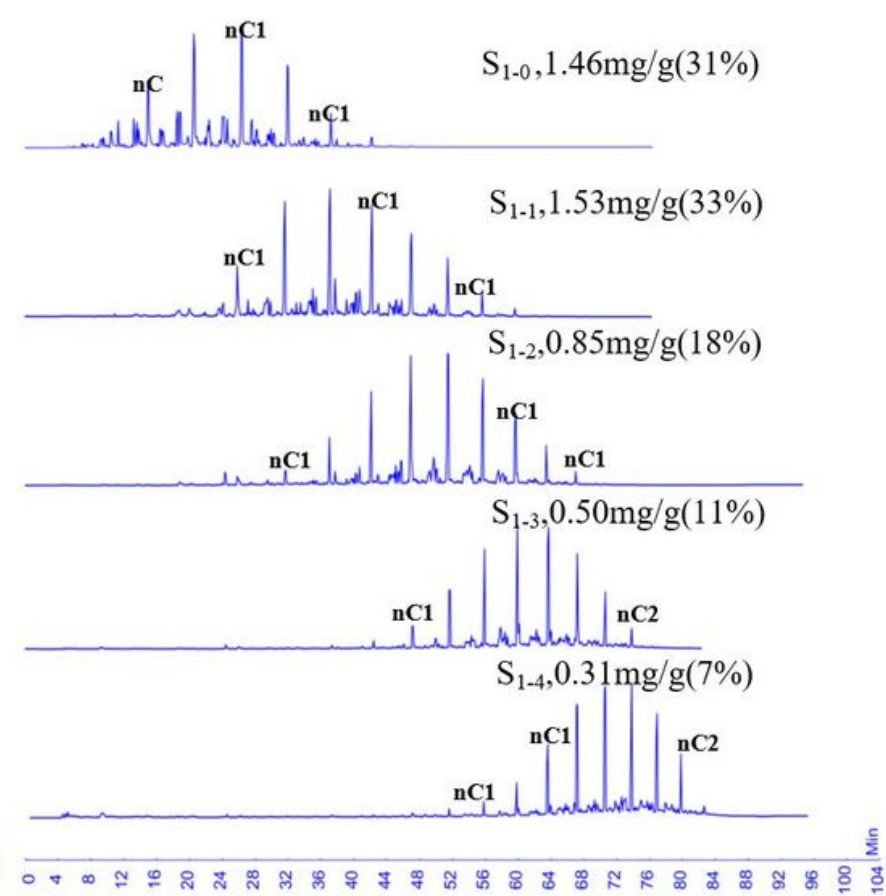

Shale samples frozen by liquid nitrogen in well Gy1,2570.65m

$\left(\mathrm{S}_{1}=4.65 \mathrm{mg} / \mathrm{g}, \mathrm{Ro}=1.67 \%\right)$

Figure 1

Analysis of oil content and molecular composition of frozen (liquid nitrogen) shale fraction collected from drilling site 


$$
\mathrm{S}_{1-0}, 0 \mathrm{mg} / \mathrm{g}(0 \%)
$$

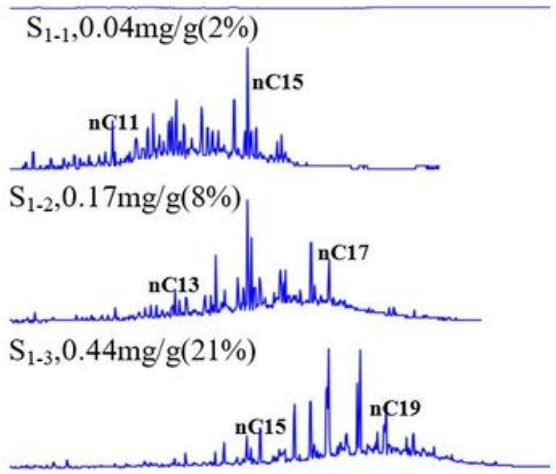

$\mathrm{S}_{1-4}, 1.42 \mathrm{mg} / \mathrm{g}(69 \%)$
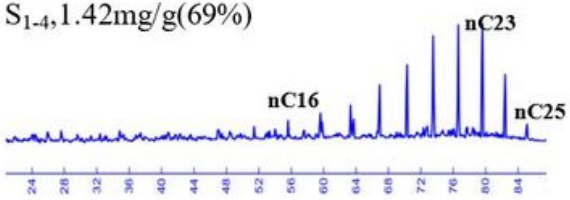

Pu53,Shale, $1625.3 \mathrm{~m}$

$\left(\mathrm{S}_{1}=2.09 \mathrm{mg} / \mathrm{g}, \mathrm{Ro}=0.83 \%\right)$
$\mathrm{S}_{1-0}, 0.0 \mathrm{mg} / \mathrm{g}(0 \%)$

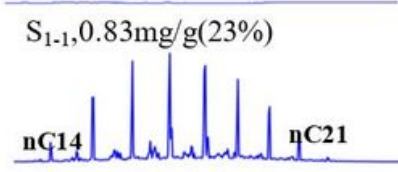

$\mathrm{S}_{1-2}, 1.19 \mathrm{mg} / \mathrm{g}(33 \%)$
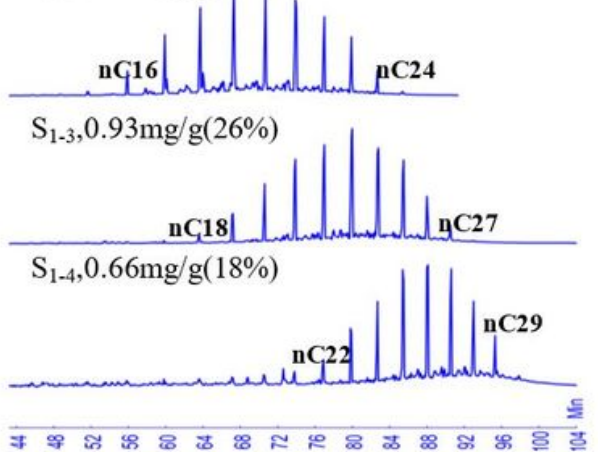

Syy2,Shale, $2135.78 \mathrm{~m}$

$\left(\mathrm{S}_{1}=3.61 \mathrm{mg} / \mathrm{g}, \mathrm{Ro}=1.19 \%\right)$
$\mathrm{S}_{1-0}, 0.06 \mathrm{mg} / \mathrm{g}(2 \%)$

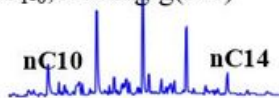

$\mathrm{S}_{1-1}, 0.63 \mathrm{mg} / \mathrm{g}(19 \%)$

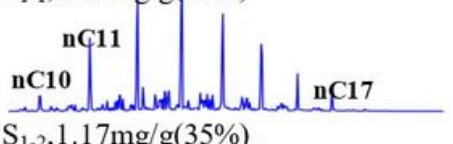

$\mathrm{S}_{1-2}, 1.17 \mathrm{mg} / \mathrm{g}(35 \%)$

nG12

nC11

nerer

$\mathrm{S}_{1-3}, 1.27 \mathrm{mg} / \mathrm{g}(39 \%)$

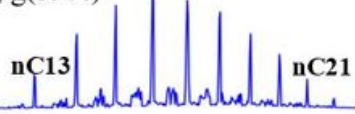

$\mathrm{S}_{1-4}, 0.16 \mathrm{mg} / \mathrm{g}(5 \%)$

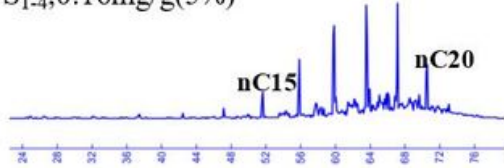

Gy 1 ,Shale, $2557.36 \mathrm{~m}$

$\left(\mathrm{S}_{1}=3.29 \mathrm{mg} / \mathrm{g}, \mathrm{Ro}=1.67 \%\right)$

Figure 2

Simultaneous analysis of oil content and molecular composition of shale fractions collected from core library 